University of Montana

ScholarWorks at University of Montana

\title{
The Advantages of Clonal Integration Under Different Ecological Conditions: a Community-Wide Test
}

Steven C. Pennings

Ragan M. Callaway

University of Montana - Missoula, Ray.Callaway@mso.umt.edu

Follow this and additional works at: https://scholarworks.umt.edu/biosci_pubs

Part of the Biology Commons

Let us know how access to this document benefits you.

\section{Recommended Citation}

Pennings, Steven C. and Callaway, Ragan M., "The Advantages of Clonal Integration Under Different Ecological Conditions: a Community-Wide Test" (2000). Biological Sciences Faculty Publications. 218. https://scholarworks.umt.edu/biosci_pubs/218

This Article is brought to you for free and open access by the Biological Sciences at ScholarWorks at University of Montana. It has been accepted for inclusion in Biological Sciences Faculty Publications by an authorized administrator of ScholarWorks at University of Montana. For more information, please contact scholarworks@mso.umt.edu. 


\title{
THE ADVANTAGES OF CLONAL INTEGRATION UNDER DIFFERENT ECOLOGICAL CONDITIONS: A COMMUNITY-WIDE TEST
}

\author{
Steven C. Pennings ${ }^{1.3}$ and Ragan M. Callaway ${ }^{2}$ \\ ${ }^{1}$ University of Georgia Marine Institute, Sapelo Island, Georgia 31327 USA \\ ${ }^{2}$ Division of Biological Sciences, University of Montana, Missoula, Montana 59812 USA
}

\begin{abstract}
The "connectedness" of clonal plants has been shown to promote survival and growth in a variety of single-species, single-factor studies, but experiments comparing the relative advantages of clonality across multiple habitats and species are rare, raising the concern that generalizations about the benefits of clonality might be biased by the particular species or habitat studied. We studied the importance of clonal integration in southeastern USA salt marsh plants, using all six of the common clonal species in the community, by following the success of intact and severed clonal fragments invading three habitat treatments.

Clonal integration was most important for growth of clonal fragments invading hypersaline salt pans, likely because parent clones supplied salt-stressed fragments with water; of moderate importance for fragments invading the neighbors-clipped treatment, likely because parent clones supplied fragments with resources enabling rapid exploitation of unused patches; and least important when neighbors were present, consistent with suggestions that size-based asymmetrical competition is relatively unimportant in clonal plants. Our results indicate that the importance of clonal integration can differ between habitats and species within a community. We encourage explicit consideration of these potential sources of variability to best understand the importance of clonal integration in the field.

Key words: abiotic stress; clonal integration; clonal plants; disturbance; halophytes; plant communities; salt marsh ecology.
\end{abstract}

\section{INTRODUCTION}

Clonal plants can share resources (Alpert and Mooney 1986, Marshall 1990, Alpert 1996, Wijesinghe and Hutchings 1997) and redistribute photosynthate (Tissue and Nobel 1988, Kemball and Marshall 1995) among ramets in patchy environments. These advantages allow clonal plants to forage for resources and select habitat (Salzman 1985, de Kroon and Knops 1990, Evans and Cain 1995, Shumway 1995, Brewer and Bertness 1996), and to support individual ramets experiencing physical stress, competition, and herbivory (Hartnett and Bazzaz 1985, Salzman and Parker 1985, Jónsdóttir and Callaghan 1989, Evans 1991, Williams and Briske 1991, Hester et al. 1994, Brewer and Bertness 1996). In many laboratory and field studies in a variety of environments, ramets that were physiologically integrated had clear growth advantages over ramets that were experimentally separated (Hartnett and Bazzaz 1983, 1985, Jónsdóttir and Callaghan 1988, Evans 1988, 1991, 1992, Lau and Young 1988, Schmid et al. 1988, Alpert 1991, Evans and Whitney 1992, Stuefer et al. 1996, Terrados et al. 1997).

Information on specific physiological and autecological benefits of clonal integration has greatly increased during the last decade; however, we know very

Manuscript received 8 June 1998; revised 22 December 1998; accepted 8 January 1999.

${ }^{3}$ E-mail: scpenn@peachnet.campuscwix.net little about the relative importance of clonality under different conditions. We are unaware of any studies that have experimentally compared the relative importance of clonal integration with respect to more than one of the fundamental advantages reported in the literature: tolerance of abiotic stress, competitive ability, exploiting resource-rich patches, or tolerance of disturbance. Moreover, only a few studies of clonal integration have examined two or more plant species simultaneously (e.g., Schmid and Bazzaz 1987, Schmid et al. 1988, de Kroon and Knops 1990, de Kroon et al. 1992, 1996, Brewer and Bertness 1996). The relative lack of comparative research raises the concern that generalizations about the advantages of clonality could be biased by choices of particular experimental habitats or species.

We took a community-wide approach to comparing whether clonality confers particular advantages for coping with abiotic stress, competing with neighbors, or exploiting patches lacking neighbors. The plant biomass of southeastern USA salt marshes is overwhelmingly dominated by clonal species that occupy habitats that vary widely in abiotic and biotic conditions. We examined all the common clonal species in the plant community, thereby avoiding a bias towards any particular species. Plants in southeastern marshes regularly experience hypersaline conditions fringing salt pans (Antlfinger and Dunn 1979, 1983, Weigert and Freeman 1990, Nomann and Pennings 1998), strong 


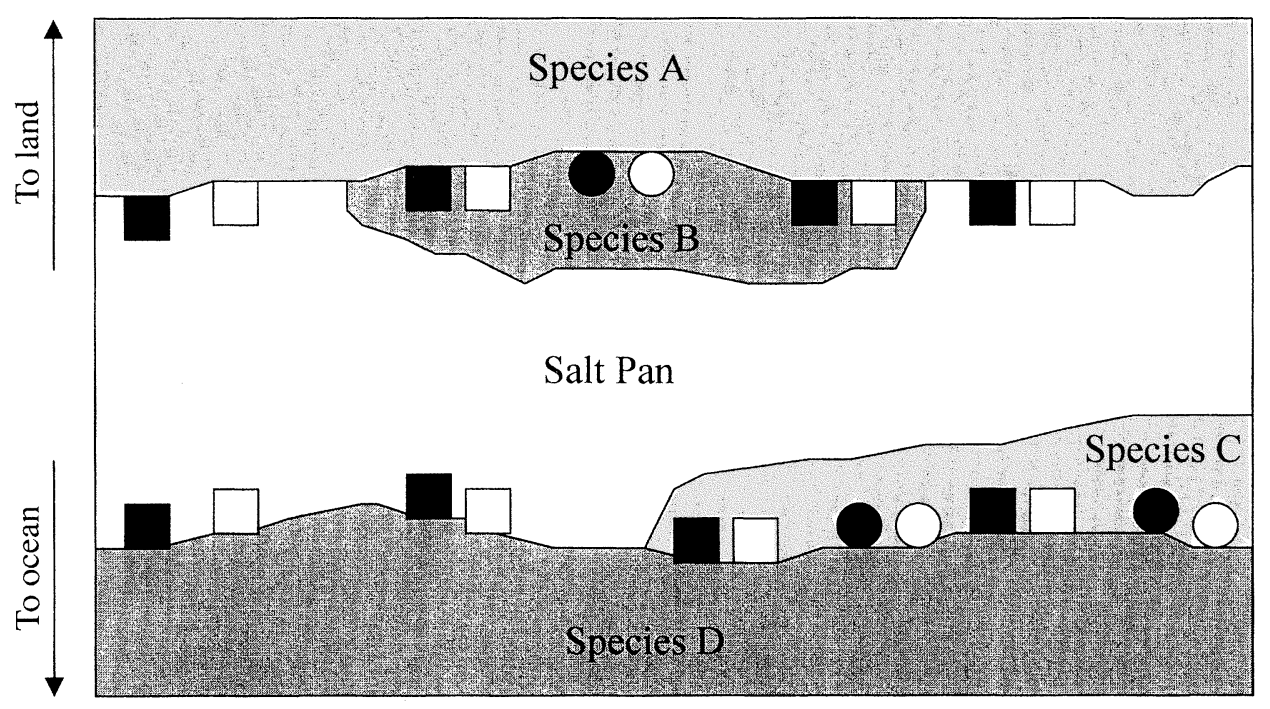

FIG. 1. Diagram illustrating key aspects of the experimental layout. Shown are four plant species and the salt pan, arranged in characteristic bands parallel to the shore. Clonal fragments of species A and D are indicated by squares (no manipulation of neighbors) or circles (neighbors removed by clipping). Not all replicates are shown. Clonal fragments were severed (solid symbols) or not severed (open symbols) from parent clones. Note that severed and intact treatments were fully interspersed. Additionally, for clonal fragments invading competitors, neighbors-clipped and neighbors-present treatments were fully interspersed. Because different species and salt pan habitat occur in particular areas of the marsh, replicates of different species were physically segregated, replicates of a particular species invading the salt pan were not fully interspersed with replicates of the same species invading a competitor, and it was impossible to use a common competitor for all six target species.

competition from neighboring plants (Bertness and Ellison 1987, Bertness 1991 $a, b$, Shumway and Bertness 1994), and disturbance from wrack deposition which can create unvegetated patches (Bertness and Ellison 1987, Valiela and Rietsma 1995). All of these factors can vary markedly in intensity over less than a meter, whereas individual clones can extend over tens of meters, indicating that clonal integration could be very important to plant success, particularly at the edges of clones where plants may be attempting to occupy new habitats.

We focused on three habitat treatments: salt pans, neighbors-present, and neighbors-clipped (to mimic effects of wrack disturbance). Because the most striking examples of the benefits of clonal integration have come from cases where ramets experienced different limiting resources (e.g., Alpert and Mooney 1986, Evans 1991, 1992, Evans and Whitney 1992, Shumway 1995, de Kroon et al. 1996, Stuefer et al. 1996), we hypothesized that clonal integration would be most important for plants invading salt pans, where hypersalinity creates extremely negative water potentials. Based on some studies suggesting that, at least under certain conditions, clonal integration does not markedly affect competitive ability (Schmid and Bazzaz 1987, de Kroon et al. 1992, de Kroon 1993, Hartnett 1993, but see Hartnett and Bazzaz 1985, Williams and Briske 1991, de Kroon and Kalliola 1995), we hypothesised that clonal integration would be least important for plants surrounded by neighbors.

\section{METHODS}

Research was conducted on the southern end of Sapelo Island, Georgia, USA $\left(31^{\circ} 27^{\prime} \mathrm{N}, 81^{\circ} 15^{\prime} \mathrm{W}\right)$ at sites locally known as Lighthouse Marsh and Marsh Landing (see Fig. 1 in Nomann and Pennings 1998). The marshes of Sapelo Island are typical southeastern USA coastal salt marshes (Pomeroy and Weigert 1981, Weigert and Freeman 1990). The plant community is dominated by six clonal species (Batis maritima, Borrichia frutescens, Distichlis spicata, Juncus roemerianus, Salicornia virginica, and Spartina alterniflora) that comprise $>99 \%$ of the plant biomass. We refer to these plants by their generic names hereafter. The terrestrial border of the high marsh is dominated by Borrichia and Juncus; Batis, Distichlis, and Salicornia occur at medium to high elevations associated with hypersaline soils; Spartina dominates lower marsh elevations. Other clonal species (e.g., Spartina patens) and nonclonal species (e.g., Salicornia europaea, S. bigelovii) occur but are rare. Permanent unvegetated salt pans with hypersaline soils are typical of upper marsh habitats. Stratified random sampling in vegetated and unvegetated zones near experimental plots indicated that salt pan soils were drier, saltier, and more nutrient poor than were vegetated zone soils (water content, 31 $\pm 4 \%$ of total wet mass (mean $\pm 1 \mathrm{SE}$ ) vs. $46 \pm 2 \%$, $n=12,30, P=0.003$; pore water salinity, $74 \pm 12$ $\mathrm{g} / \mathrm{kg}$ vs. $44 \pm 2 \mathrm{~g} / \mathrm{kg}, n=12,30, P=0.02 ; \mathrm{NH}_{4}, 2.6$ $\pm 1.2 \mu \mathrm{g} / \mathrm{g}$ vs. $7.4 \pm 2.8 \mu \mathrm{g} / \mathrm{g}, n=8,16, P=0.03$; 


\begin{tabular}{|c|c|c|c|c|c|}
\hline & Species & $\begin{array}{l}\text { Study } \\
\text { site }\end{array}$ & $\begin{array}{l}\text { Initial size } \\
\text { of clonal } \\
\text { fragment }\end{array}$ & $\begin{array}{l}\text { Competitor } \\
\text { species }\end{array}$ & $\begin{array}{l}\text { Method used } \\
\text { to estimate } \\
\text { size }\end{array}$ \\
\hline 和布 & $\begin{array}{l}\text { Batis } \\
\text { maritima }\end{array}$ & Lighthouse & $\sim 10 \%$ cover & $\begin{array}{l}\text { Salicornia } \\
\text { virginica }\end{array}$ & $\begin{array}{c}\text { Percent cover, } \\
0.5 \times 0.5 \mathrm{~m} \text { quadrat }\end{array}$ \\
\hline & $\begin{array}{l}\text { Borrichia } \\
\text { frutescens }\end{array}$ & Lighthouse & $\begin{array}{l}\text { Single shoot, } \\
\sim 20 \text { leaves }\end{array}$ & $\begin{array}{l}\text { Batis } \\
\text { maritima }\end{array}$ & Number of leaves \\
\hline 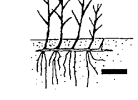 & $\begin{array}{l}\text { Distichlis } \\
\text { spicata }\end{array}$ & $\begin{array}{l}\text { Marsh } \\
\text { landing }\end{array}$ & 2 emergent shoots & $\begin{array}{l}\text { Batis } \\
\text { maritima }\end{array}$ & $\begin{array}{l}\text { Sum of lengths } \\
\text { of all shoots }\end{array}$ \\
\hline$\frac{\text { My }}{3 \times n}=$ & $\begin{array}{c}\text { Juncus } \\
\text { roemerianus }\end{array}$ & $\begin{array}{l}\text { Marsh } \\
\text { landing }\end{array}$ & $\begin{array}{l}\sim 10 \text { emergent } \\
\text { shoots }\end{array}$ & $\begin{array}{l}\text { Salicornia } \\
\text { virginica }\end{array}$ & $\begin{array}{l}\text { Sum of lengths } \\
\text { of all shoots }\end{array}$ \\
\hline 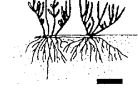 & $\begin{array}{l}\text { Salicornia } \\
\text { virginica }\end{array}$ & Lighthouse & $\sim 10 \%$ cover & $\begin{array}{l}\text { Spartina } \\
\text { alterniflora }\end{array}$ & $\begin{array}{c}\text { Percent cover, } \\
0.5 \times 0.5 \mathrm{~m} \text { quadrat }\end{array}$ \\
\hline 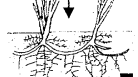 & $\begin{array}{l}\text { Spartina } \\
\text { alterniflora }\end{array}$ & Lighthouse & $\begin{array}{l}\text { Single emergent } \\
\text { shoot }\end{array}$ & $\begin{array}{l}\text { Salicornia } \\
\text { virginica }\end{array}$ & $\begin{array}{l}\text { Sum of lengths } \\
\text { of all shoots }\end{array}$ \\
\hline
\end{tabular}

FIG. 2. Details of the design of the severing experiment. Drawings illustrate general features of plant shape; bars indicate $10 \mathrm{~cm}$; arrows indicate approximate locations where rhizomes were severed.

$\mathrm{NO}_{3}, 0.37 \pm 0.19 \mu \mathrm{g} / \mathrm{g}$ vs. $0.69 \pm 0.13 \mu \mathrm{g} / \mathrm{g}, n=8$, $16, P=0.07)$. Temporary unvegetated areas are often created by tidally deposited mats of wrack (dead plant stems), which can kill underlying vegetation (Bertness and Ellison 1987, S. C. Pennings, personal observation). Deposited wrack may decompose in place or may be removed by subsequent tides leaving an unvegetated patch of bare soil. If bare patches are small, salinities are not markedly elevated above ambient conditions (Shumway and Bertness 1994; S. C. Pennings, personal observation). All of the plant species that we worked with commonly occur in monospecific patches that can border other plant species and both types of bare space.

To examine the importance of clonal integration in this community, we conducted an experiment with all six common clonal species that crossed two clonal integration treatments (severed, intact) with three habitat treatments (salt pan, neighbors-present, neighborsclipped). Because the species included a variety of growth forms, we use the words "rhizome" and "shoot" generically to refer to all connections between ramets and all aboveground supportive or photosynthetic material. Severing rhizome connections mimics natural losses of clonal connections, and is a standard and useful approach to studying the importance of clonal integration, but does suffer from some potential artifacts such as initial trauma and the possible introduction of disease (Kelly 1995). A number of studies have found no effect of severing connections under control conditions, indicating that these artifacts are not necessarily severe (Hartnett and Bazzaz 1983, Alpert 1991, Evans 1991, 1992, Evans and Whitney 1992, Hester et al. 1994). We did not rigorously evaluate the importance of potential artifacts of severing in our system; however, we did not observe any patterns of sudden death or increased disease that would suggest that important artifacts occurred.

Key aspects of the experimental layout are illustrated in Fig. 1. For each species, we located clones that were invading salt pans or stands of another species. Based on our previous experiences transplanting and/or examining the root systems of these species, we placed a flag adjacent to the rhizome so that plant material distal to the flag was as small as possible while still including sufficient roots to be viable (Fig. 2). Half of the clonal fragments were severed from their parent 
clone with a blade at the location marked by the flag. We cut into the soil adjacent to intact replicates to control for soil disturbance. Severed and intact treatments were fully interspersed. For the neighbors-present and neighbors-clipped treatments, we paired each species with its most common neighbor (Fig. 2). To create the neighbors-clipped treatment, we removed aboveground vegetation by clipping within a $25-\mathrm{cm}$ border around the clonal fragment. Neighbor removal was maintained by periodic clipping. Since belowground neighbors were not removed, competition was probably reduced but not completely eliminated. For each species, neighbors-present and neighbors-clipped treatments were fully interspersed. Sample sizes were 8-11 for each species/severing/habitat combination.

Because salt pans and different plant species occur nonrandomly in different parts of the marsh, we could not use a single plant species as a common competitor (i.e., a phytometer, sensu Clements 1935, Keddy 1989, Keddy et al. 1994), nor could we fully intersperse replicates with different plant species or treatments (i.e., high vs. low elevation borders, salt pan vs. neighbor treatments). This would have been possible in a laboratory study; however, since our goal was to examine the importance of clonality under natural conditions in the field, it seemed appropriate to study these interactions under the conditions (marsh zone, microhabitat, and competitor species) in which they most typically occurred.

Treatments were initiated and runner size measured on 14-16 June, 1995. Final size measurements were taken on 26 July for Distichlis (a number of flags marking Distichlis replicates were lost after this date), and 30 October 1995 for all other species. Since Distichlis grows rapidly, the shorter observation period for this species did not limit our ability to measure growth rate. In order to take initial size of clonal fragments into account, we looked at the percent change of nondestructive estimators of size. Because the six plant species had different growth forms, we used different measures that we felt would best estimate size for each species (Fig. 2). Size of grasses and rushes (Distichlis, Juncus, and Spartina) was estimated using total shoot length (the sum of the heights of all the shoots), size of the erect shrub (Borrichia) was estimated using leaf number (a count of all leaves), and size of bushy succulents (Batis and Salicornia) was estimated using percent cover (percentage of $25-\mathrm{cm}^{2}$ cells occupied in a $0.25-\mathrm{m}^{2}$ quadrat, sensu Pennings and Callaway 1992). These measures are highly correlated with aboveground dry mass over the size range of clonal fragments that we studied (Batis, $r=0.85, n=20, P<0.0001$; Borrichia, $r=0.58, n=274, P<0.0001$; Distichlis, $r=0.91, n=128, P<0.0001 ;$ Juncus, $r=0.97, n$ $=327, P<0.0001 ;$ Spartina, $r=0.87, n=262, P$ $<0.0001$; linear model provided the best fit in all cases [S. C. Pennings and R. M. Callaway, unpublished data]). We do not have similar data for Salicornia, but
TABLE 1. Three-way ANOVA results ( $F$ and $P$ values) for effects of severing clonal connections of six species in three habitat treatments.

\begin{tabular}{lrrl}
\hline \multicolumn{1}{c}{ Effect } & \multicolumn{1}{c}{$F$} & \multicolumn{1}{c}{ df } & \multicolumn{1}{c}{$P$} \\
\hline Sever & 153.07 & 2,323 & 0.0001 \\
Habitat & 0.91 & 2,323 & 0.41 \\
Species & 56.00 & 5,323 & 0.0001 \\
Habitat $\times$ species & 9.52 & 10,323 & 0.0001 \\
Sever $\times$ habitat & 10.89 & 2,323 & 0.0001 \\
Sever $\times$ species & 7.15 & 5,323 & 0.0001 \\
Sever $\times$ habitat $\times$ species & 1.27 & 10,323 & 0.25 \\
\hline
\end{tabular}

expect that the correlation would be similar to that of Batis since the two species have similar growth forms. Data on percent change in size (which was calculated as 100 [ [final size - initial size]/initial size) were $\log _{e^{-}}$ transformed to improve homogeneity of variance (a constant was added so that all values were positive) and analyzed with three-way ANOVA, with species, severing treatment, and habitat treatment as main effects. Clonal fragments that died ( $7 \%$ of total) were included in the analysis of growth with their growth recorded as $-100 \%$. Analyzing mortality and growth separately yielded similar patterns but was less powerful because of smaller sample sizes.

\section{RESUlts}

Severing clonal connections often dramatically reduced growth of clonal fragments; however, this effect differed between habitat treatments and between species (Fig. 3, Table 1; significant sever $\times$ habitat and sever $\times$ species interaction effects). To examine the sever $\times$ habitat interaction more closely, we conducted separate ANOVAs for each habitat. Significant main effects of severing were seen in the salt flat and neighbors-clipped habitats, but not when neighbors were present (Table 2). To examine the sever $\times$ species interaction more closely, we conducted separate ANOVAs for each species. Significant main effects of severing were seen for all species except Salicornia (Table 3), but inspection of the $F$-values and treatment means (Fig. 3) suggests that the effect of severing was modest for Spartina and severe for Batis, Borrichia, Distichlis, and Juncus.

\section{Discussion}

Our comparison of six different clonal salt marsh species demonstrated that the importance of clonal integration differed markedly between salt marsh microhabitats. Clonal integration was very important for plants invading the salt pan, moderately important for plants exploiting the neighbors-clipped treatment, and least important for plants with neighbors present. The importance of clonal integration also appeared to differ between species, but this conclusion must be tentative because of the different methods used for plants with different growth forms. 

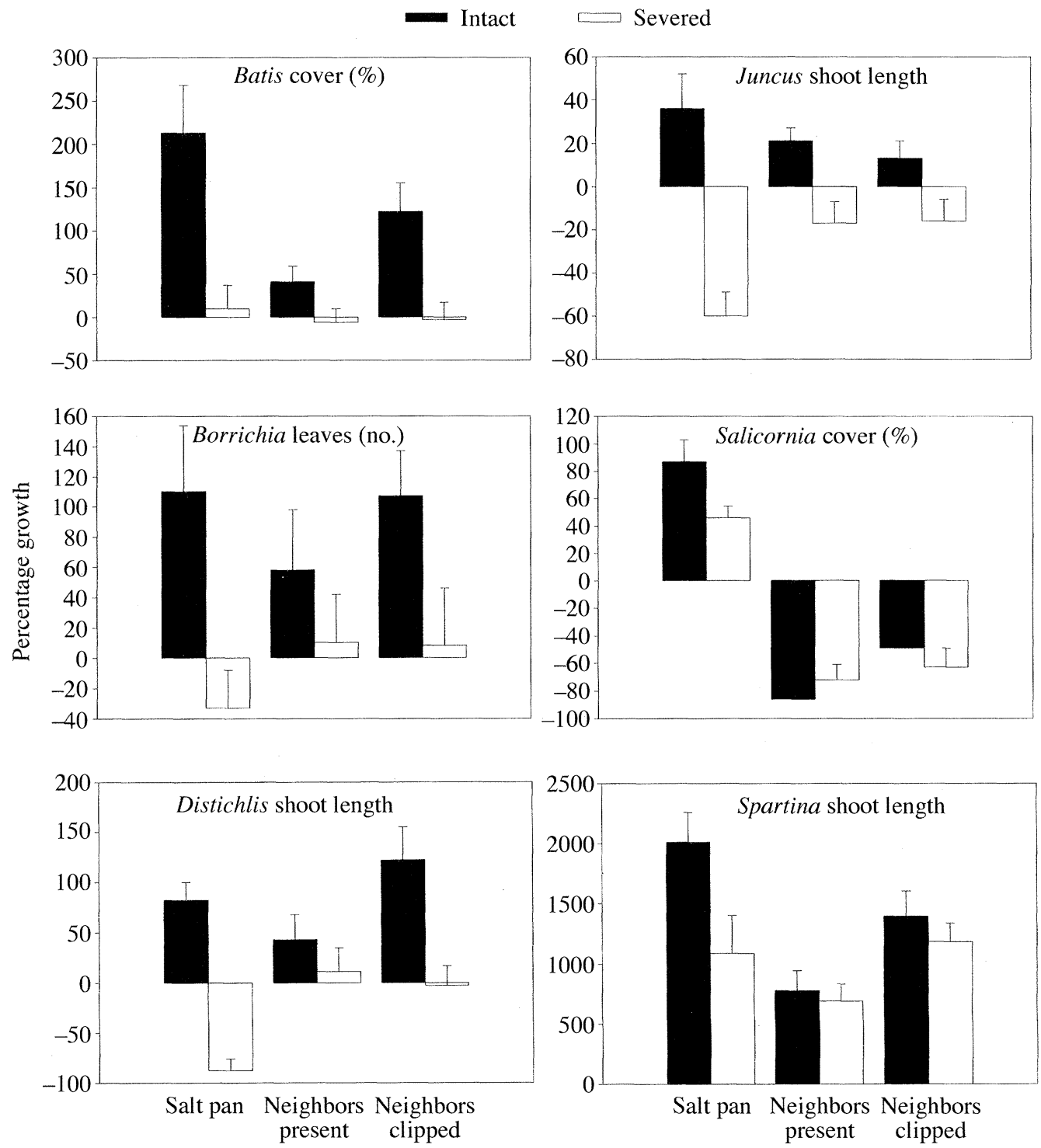

FIG. 3. Percentage growth of intact and severed clonal fragments of six species of salt marsh plant in three habitat treatments. Data are means +1 SE.

Clonal integration was very important for plants invading the salt pan, probably because of the high salinities (commonly $>100 \mathrm{~g} / \mathrm{kg}$ ) found in this habitat (Antlfinger and Dunn 1979, 1983, Nomann and Pennings 1998). The importance of clonal integration for tolerating salt stress has been emphasized by others (Salzman and Parker 1985). Clonal integration buffered Hydrocotyle bonariensis from salt stress as ramets invaded salt marshes (Evans and Whitney 1992), reduced the stress response of Spartina patens to high salinity

TABLE 2. Results ( $F$ and $P$ values) of two-way ANOVAs, by habitat, for effects of severing clonal connections of six species in three habitat treatments.

\begin{tabular}{|c|c|c|c|c|c|c|c|c|c|}
\hline \multirow[b]{2}{*}{ Effect } & \multicolumn{3}{|c|}{ Salt pan } & \multicolumn{3}{|c|}{ Neighbors present } & \multicolumn{3}{|c|}{ Neighbors clipped } \\
\hline & $F$ & df & $P$ & $F$ & $\mathrm{df}$ & $P$ & $F$ & $\mathrm{df}$ & $P$ \\
\hline Sever & 12.35 & 1,108 & 0.0006 & 1.08 & 1,108 & 0.30 & 5.61 & 1,107 & 0.02 \\
\hline Species & 49.40 & 5,108 & 0.0001 & 40.70 & 5,108 & 0.0001 & 86.45 & 5,107 & 0.0001 \\
\hline Sever $\times$ Species & 3.50 & 5,108 & 0.006 & 0.12 & 5,108 & 0.99 & 0.46 & 5,107 & 0.81 \\
\hline
\end{tabular}


TABLE 3. Results of two-way ANOVAs, by species, for effects of severing clonal connections of six species in three habitat treatments.

\begin{tabular}{|c|c|c|c|c|c|c|c|c|c|}
\hline \multirow[b]{2}{*}{ Effect } & \multicolumn{3}{|c|}{ Batis } & \multicolumn{3}{|c|}{ Borrichia } & \multicolumn{3}{|c|}{ Distichlis } \\
\hline & $F$ & df & $P$ & $F$ & df & $P$ & $F$ & df & $P$ \\
\hline Sever & 13.34 & 1,53 & 0.0006 & 12.59 & 1,54 & 0.0008 & 44.27 & 1,53 & 0.0001 \\
\hline Habitat & 0.01 & 2,53 & 0.99 & 0.19 & 2,54 & 0.83 & 9.22 & 2,53 & 0.0004 \\
\hline Sever $\times$ Habitat & 1.57 & 2,53 & 0.22 & 1.26 & 2,54 & 0.29 & 10.19 & 2,53 & 0.0002 \\
\hline
\end{tabular}

in the laboratory (Hester et al. 1994), and allowed ramets of Distichlis to colonize hypersaline areas in New England marshes (Shumway 1995). de Kroon et al. (1996) used deuterium labeling to show that 30-60\% of the water acquired by Carex spp. ramets could be exported to other, water-deficient ramets. More generally, clonal integration has commonly been found to be important when individual ramets experience contrasting environments, and thus can provide different limiting resources to the clone (Alpert and Mooney 1986, Evans 1991, 1992, Evans and Whitney 1992, Stuefer et al. 1996, Wijesinghe and Hutchings 1997). As found by Shumway (1995), we suspect that ramets invading salt pans were a net sink for water, but because they escaped the shade of neighbors, may have been a net source for photosynthate.

Clonal integration was moderately important for plants invading patches with neighbors clipped. The ability of clonal plants to translocate resources to daughter ramets may be very advantageous when quick growth by daughter ramets would allow rapid exploitation of unutilized patches, and a variety of studies have explored the possibility that clonal integration may allow plants to actively forage for resources (Salzman 1985, de Kroon and Knops 1990, Cain 1994, Evans and Cain 1995, Shumway 1995, Brewer and Bertness 1996, Stuefer et al. 1996, Charpentier et al. 1998, Stoll et al. 1998).

Clonal integration was least important for plants surrounded by neighbors. Although several species showed a trend toward reduced growth when severed in the neighbors-present treatment, this was not significant. Previous studies have disagreed about the importance of clonal integration for competitive ability. Schmid and Bazzaz (1987) reported that severing clonal connections of Aster and Solidago species had minimal effects on inter- or intraspecific competition. Similarly, de Kroon et al. (1992) suggested that clonal integration did not affect intraspecific competition in Brachypodium pinnatum or Carex flacca. In contrast, Hartnett and Bazzaz (1985) demonstrated that the response of Solidago canadensis ramets to interspecific competition was affected by the experiences of connected ramets. It is unlikely that our failure to find an effect of severing on ramets amidst neighbors was caused by weak interspecific interactions. Many studies have documented intense competition at borders between salt marsh plants (Silander and Antonivics 1982, Bertness and Ellison 1987, Bertness 1991 $a$, b, Pennings and Callaway 1992), and growth of most species in our experiments appeared poorer in competition than in other habitats. de Kroon and colleagues suggested that intraspecific competition among clonal fragments is size symmetric, rather than asymmetric, and hence that clonal integration may be relatively unimportant in mediating the outcome of intraspecific competition in dense monocultures (de Kroon et al. 1992, de Kroon 1993), but whether their ideas explain our results in interspecific mixtures is a matter for further study.

The importance of clonal integration appeared to differ between species. In particular, severing rhizomes of Salicornia and Spartina reduced growth by modest amounts compared to the impacts observed on other species. These results must be interpreted with caution because of the different methods used with plants of different growth forms. Differences between species could have been due either to fundamental differences in clonal integration between species or to details of the methods such as the initial size of the clonal fragment and the technique used to measure size. Either case would be of interest, and deserves further attention.

Salt stress, secondary succession, and competition are all important processes in coastal salt marshes (Bertness and Ellison 1987, Bertness 1991a, b, Bertness et al. 1992, Pennings and Callaway 1992, Shumway and Bertness 1994, Shumway 1995). Our results suggest that clonal integration is not equally important to all these processes. Clonal integration was very important for plants invading hypersaline salt pans, moderately important for plants exploiting patches lacking neighbors, and of little importance for plants in the neighbors-present treatment. Since results can vary between habitats and species within a community, we encourage explicit consideration of these potential sources of variability to best understand the importance of clonal integration in the field.

\section{ACKNOWLEDGMENTS}

We thank Mike Livingston, Ben Nomann, and JoanMarie Svedberg for help in the field. R. M. Callaway's visit to Sapelo Island was supported by the Sapelo Foundation through the Visiting Scientist Program at the University of Georgia Marine Institute. We thank M. Bertness, H. de Kroon, L. Donovan, J. Stuefer, and two anonymous reviewers for helpful comments on the manuscript. This is contribution number 826 from the University of Georgia Marine Institute. 
TABle 3. Extended

\begin{tabular}{|c|c|c|c|c|c|c|c|c|}
\hline \multicolumn{3}{|c|}{ Juncus } & \multicolumn{3}{|c|}{ Salicornia } & \multicolumn{3}{|c|}{ Spartina } \\
\hline$F$ & $\mathrm{df}$ & $P$ & $F$ & $\mathrm{df}$ & $P$ & $F$ & $\mathrm{df}$ & $P$ \\
\hline 17.34 & 1,53 & 0.0001 & 0.35 & 1,55 & 0.56 & 4.38 & 1,55 & 0.04 \\
\hline 4.53 & 2,53 & 0.015 & 24.22 & 2,55 & 0.0001 & 8.78 & 2,55 & 0.0005 \\
\hline 5.63 & 2,53 & 0.006 & 0.32 & 2,55 & 0.73 & 2.47 & 2,55 & 0.09 \\
\hline
\end{tabular}

\section{Literature Cited}

Alpert, P. 1991. Nitrogen sharing among ramets increases clonal growth in Fragaria chiloensis. Ecology 72:69-80.

Alpert, P. 1996. Nutrient sharing in natural clonal fragments of Fragaria chiloensis. Journal of Ecology 84:395-406.

Alpert, P., and H. A. Mooney. 1986. Resource sharing among ramets in the clonal herb, Fragaria chiloensis. Oecologia 70:227-233.

Antlfinger, A. E., and E. L. Dunn. 1979. Seasonal patterns of $\mathrm{CO}_{2}$ and water vapor exchange of three salt marsh succulents. Oecologia 43:249-260.

Antlfinger, A. E., and E. L. Dunn. 1983. Water use and salt balance in three salt marsh succulents. American Journal of Botany 70:561-567.

Bertness, M. D. 1991a. Interspecific interactions among high marsh perennials in a New England salt marsh. Ecology 72:125-137.

Bertness, M. D. 1991b. Zonation of Spartina patens and Spartina alterniflora in a New England salt marsh. Ecology 72: $138-148$.

Bertness, M. D., and A. M. Ellison. 1987. Determinants of pattern in a New England salt marsh plant community. Ecological Monographs 57:129-147.

Bertness, M. D., L. Gough, and S. W. Shumway. 1992. Salt tolerances and the distribution of fugitive salt marsh plants. Ecology 73:1842-1851.

Brewer, J. S., and M. D. Bertness. 1996. Disturbance and intraspecific variation in the clonal morphology of salt marsh perennials. Oikos 77:107-116.

Cain, M. L. 1994. Consequences of foraging in clonal plant species. Ecology 75:933-944.

Charpentier, A., F. Mesléard, and J. D. Thompson. 1998. The effects of rhizome severing on the clonal growth and clonal architecture of Scirpus maritimus. Oikos 83:107-116.

Clements, F. E. 1935. Ecology in the public service. Ecology 16:246.

de Kroon, H. 1993. Competition between shoots in stands of clonal plants. Plant Species Biology 8:85-94.

de Kroon, H., B. Fransen, J. W. A. van Rheenen, A. van Dijk, and R. Kreulen. 1996. High levels of inter-ramet water translocation in two rhizomatous Carex species, as quantified by deuterium labelling. Oecologia 106:73-84.

de Kroon, H., T. Hara, and R. Kwant. 1992. Size hierarchies of shoots and clones in clonal herb monocultures: do clonal and non-clonal plants compete differently? Oikos 63:410 419.

de Kroon, H., and R. Kalliola. 1995. Shoot dynamics of the giant grass Gynerium sagittatum in Peruvian Amazon floodplains, a clonal plant that does show self-thinning. Oecologia 101:124-131.

de Kroon, H., and J. Knops. 1990. Habitat exploration through morphological plasticity in two chalk grassland perennials. Oikos 59:39-49.

Evans, J. P. 1988. Nitrogen translocation in a clonal dune perennial, Hydrocotyle bonariensis. Oecologia 77:64-68.

Evans, J. P. 1991. The effect of resource integration on fitness related traits in a clonal dune perennial, Hydrocotyle bonariensis. Oecologia 86:268-275.
Evans, J. P. 1992. The effect of local resource availability and clonal integration on ramet functional morphology in Hydrocotyle bonariensis. Oecologia 89:265-276.

Evans, J. P., and M. L. Cain. 1995. A spatially explicit test of foraging behavior in a clonal plant. Ecology 76:11471155.

Evans, J. P., and S. Whitney. 1992. Clonal integration across a salt gradient by a nonhalophyte, Hydrocotyle bonariensis (Apiaceae). American Journal of Botany 79:1344-1347.

Hartnett, D. C. 1993. Regulation of clonal growth and dynamics of Panicum virgatum (Poaceae) in tallgrass prairie: effects of neighbor removal and nutrient addition. American Journal of Botany 80:1114-1120.

Hartnett, D. C., and F. A. Bazzaz. 1983. Physiological integration among intraclonal ramets in Solicago canadensis. Ecology 64:779-788.

Hartnett, D. C., and F. A. Bazzaz. 1985. The integration of neighbourhood effects by clonal genets in Solidago canadensis. Journal of Ecology 73:415-427.

Hester, M. W., K. L. McKee, D. M. Burdick, M. S. Koch, K. M. Flynn, S. Patterson, and I. A. Mendelssohn. 1994. Clonal integration in Spartina patens across a nitrogen and salinity gradient. Canadian Journal of Botany 72:767-770.

Jónsdóttir, I. S., and T. V. Callaghan. 1988. Interrelationships between different generations of interconnected tillers of Carex bigelowii. Oikos 52:120-128.

Jónsdóttir, I. S., and T. V. Callaghan. 1989. Localized defoliation stress and the movement of ${ }^{14} \mathrm{C}$-photoassimilates between tillers of Carex bigelowii. New Phytologist 114: 419-428.

Keddy, P. A. 1989. Competition. Chapman and Hall, London, U.K.

Keddy, P. A., L. Twolan-Strutt, and I. C. Wisheu. 1994. Competitive effect and response rankings in 20 wetland plants: are they consistent across three environments? Journal of Ecology 82:635-643.

Kelly, C. K. 1995. Thoughts on clonal integration: facing the evolutionary context. Evolutionary Ecology 9:575-585.

Kemball, W. D., and C. Marshall. 1995. Clonal integration between parent and branch stolons in white clover: a developmental study. New Phytologist 129:513-521.

Lau, R. R., and D. R. Young. 1988. Influence of physiological integration on survivorship and water relations in a clonal herb. Ecology 69:215-219.

Marshall, C. 1990. Source-sink relations of interconnected ramets. Pages 23-41 in J. van Groenendael and $\mathrm{H}$. de Kroon, editors. Clonal growth in plants: regulation and function. SPB Academic Publishing, The Hague, The Netherlands.

Nomann, B. E., and S. C. Pennings. 1998. Fiddler crabvegetation interactions in hypersaline habitats. Journal of Experimental Marine Biology and Ecology 225:53-68.

Pennings, S. C., and R. M. Callaway. 1992. Salt marsh plant zonation: the relative importance of competition and physical factors. Ecology 73:681-690.

Pomeroy, L. R., and R. G. Wiegert. 1981. Ecology of a salt marsh. Ecological Studies Series, Volume 38. SpringerVerlag, New York, New York, USA. 
Salzman, A. G. 1985. Habitat selection in a clonal plant. Science 228:603-604.

Salzman, A. G., and M. A. Parker. 1985. Neighbors ameliorate local salinity stress for a rhizomatous plant in a heterogeneous environment. Oecologia 65:273-277.

Schmid, B., and F. A. Bazzaz. 1987. Clonal integration and population structure in perennials: effects of severing rhizome connections. Ecology 68:2016-2022.

Schmid, B., G. M. Puttick, K. H. Burgess, and F. A. Bazzaz. 1988. Clonal integration and effects of simulated herbivory in old-field perennials. Oecologia 75:465-471.

Shumway, S. W. 1995. Physiological integration among clonal ramets during invasion of disturbance patches in a New England salt marsh. Annals of Botany 76:225-233.

Shumway, S. W., and M. D. Bertness. 1994. Patch size effects on marsh plant secondary succession mechanisms. Ecology 75:564-568.

Silander, J. A., and J. Antonovics. 1982. Analysis of interspecific interactions in a coastal plant community-a perturbation approach. Nature 298:557-560.

Stoll, P., P. Egli, and B. Schmid. 1998. Plant foraging and rhizome growth patterns in Solidago altissima in response to mowing and fertilizer application. Journal of Ecology 86:341-354.
Stuefer, J. F., H. de Kroon, and H. J. During. 1996. Exploitation of environmental heterogeneity by spatial division of labour in a clonal plant. Functional Ecology 10:328334.

Terrados, J., C. M. Duarte, and W. J. Kenworthy. 1997. Is the apical growth of Cymodocea nodosa dependent on clonal integration? Marine Ecology Progress Series 158:103110.

Tissue, D. T., and P. S. Nobel. 1988. Parent-ramet connections in Agave deserti: influences of carbohydrates on growth. Oecologia 75:266-271.

Valiela, I., and C. S. Rietsma. 1995. Disturbance of salt marsh vegetation by wrack mats in Great Sippewissett Marsh. Oecologia 102:106-112.

Wiegert, R. G., and B. J. Freeman. 1990. Tidal salt marshes of the southeast Atlantic coast: a community profile. U.S. Fish and Wildlife Service, Biological Report 85 (7.29).

Wijesinghe, D. A., and M. J. Hutchings. 1997. The effects of spatial scale of environmental heterogeneity on the growth of a clonal plant: an experimental study with Glechoma hederacea. Journal of Ecology 85:17-28.

Williams, D. G., and D. D. Briske. 1991. Size and ecological significance of the physiological individual in the bunchgrass Schizachyrium scoparium. Oikos 62:41-47. 